\title{
In vitro conservation of Poincianella pyramidalis (Tul.) L.P. Queiroz under minimal growth conditions
}

\section{Conservação in vitro de Poincianella pyramidalis (Tul.) L.P. Queiroz sob condições de crescimento mínimo}

\author{
Tecla dos Santos Silva1 (D), Cristina Ferreira Nepomuceno ${ }^{2}$, \\ Taliane Leila Soares $^{1 *}$ iD , José Raniere Ferreira de Santana ${ }^{1}$ if \\ 'Universidade Estadual de Feira de Santana, Feira de Santana, BA, Brasil \\ ${ }^{2}$ Universidade Federal do Recôncavo da Bahia, Centro de Ciências Agrárias Ambientais e Biológicas, Cruz das Almas, BA, Brasil \\ *Corresponding author: talialeila@gmail.com \\ Received in June 14, 2019 and approved in September 10, 2019
}

\begin{abstract}
Poincianella pyramidalis (Tul.) L.P. Queiroz, is an arboreal species endemic to Brazil's Caatinga biome and an important source of lumber and also of medicinal substances. This study aimed to evaluate the effect of the osmotic agents sucrose, sorbitol and mannitol and the growth retardant paclobutrazol (PBZ) on the induction of slow growth in vitro of $P$. pyramidalis, seeking to establish alternative techniques for ex situ conservation of the species. In the first experiment, plantlets with seven days of age were inoculated on Woody Plant Medium (WPM) supplemented with four concentrations of sucrose $(87.64,131.46,175.28$ or $219.10 \mathrm{mM}$ ) combined with 0.0 or $87.64 \mathrm{mM}$ sorbitol or mannitol. In the second experiment, these plantlets were inoculated on WPM medium with 0.0, 1.5, 3.0, 4.5 or $6.0 \mu \mathrm{M} \mathrm{PBZ}$ and supplemented with $87.64 \mathrm{mM}$ sucrose. For both experiments, the survival percentage of the plants was evaluated every 60 days, and at the end of 240 days, the following parameters were recorded: number of green leaves and senescent leaves; length of the aerial part and longest root; and dry mass of the aerial part and roots. The best results to maintain the quality of the $P$. pyramidalis plants conserved in vitro were obtained on medium supplemented with $219.10 \mathrm{mM}$ sucrose for up to 240 days without subculture. With respect to PBZ, the concentration of $6.0 \mu \mathrm{M}$ can be recommended for in vitro conservation of $P$. pyramidalis for 240 days without the need of subculturing.
\end{abstract}

Index terms: Catingueira; osmotic agents; paclobultrazol; tissue culture.

\begin{abstract}
RESUMO
Poincianella pyramidalis (Tul.) L.P. Queiroz, é uma espécie endêmica da Caatinga, se destaca pela importância nas atividades madeireira e medicinal. Este estudo teve como objetivo avaliar o efeito dos agentes osmóticos sacarose, sorbitol e manitol e o retardante de crescimento paclobutrazol (PBZ) na indução do crescimento mínimo in vitro de $P$. pyramidalis, visando o estabelecimento de técnicas alternativas para conservação ex situ da espécie. No primeiro experimento, plântulas com sete dias de idade foram inoculadas em meio WPM suplementado com quatro concentrações de sacarose $(87,64,131,46,175,28$ ou $219,10 \mathrm{mM})$ combinadas com 0,0 ou $87,64 \mathrm{mM}$ de sorbitol ou manitol. No segundo experimento, essas plântulas foram inoculadas em meio WPM contendo diferentes concentrações $(0,0$, 1,5, 3,0, 4,5 ou 6,0 $\mu \mathrm{M}$ ) de PBZ e suplementadas com 87,64 mM de sacarose. Para ambos os experimentos, foi avaliado a porcentagem de sobrevivência das plantas a cada 60 dias. Ao final de 240 dias, foram analisados o número de folhas verdes e folhas senescentes, comprimento da parte aérea e da maior raiz, e massa seca da parte aérea e da raiz. Os melhores resultados para manter a qualidade das plantas de $P$. pyramidalis conservadas in vitro foram obtidos em meio suplementado com 219,10 mM de sacarose isolada por até 240 dias sem subcultivo. Com relação ao PBZ, a concentração de 6,0 $\mu \mathrm{M}$ pode ser recomendada para conservação in vitro de $P$. pyramidalis por um período de 240 dias sem a necessidade de subcultivos.
\end{abstract}

Termos para indexação: Catingueira; agentes osmóticos; paclobultrazol; cultura de tecidos.

\section{INTRODUCTION}

Poincianella pyramidalis (Tul.) L.P. Queiroz (syn. Caesalpinia pyramidalis Tul.) (Fabaceae). is a mediumsized arboreal species belonging to the family Fabaceae (Leguminosae), endemic to Brazil's semiarid northeastern region, with wide distribution in the Caatinga biome (Carvalho, 2014; Chaves et al., 2016; Souza et al., 2018). It is popularly known as 'catingueira', 'pau-de-rato', 'catingueira-das-folhas-largas', 'mussitaiba' and 'paude-porco' (Leite; Machado, 2009; Gomes-Copeland et al., 2017). The species has diverse potential uses, such as for 
wood and charcoal (Maia, 2004; Dias Júnior et al., 2018), for medicinal purposes (Chaves et al., 2016; Souza et al., 2018), for replanting of degraded areas and in agroforestry systems (Maia, 2012).

Poincianella pyramidalis naturally propagates sexually (Gomes-Copeland et al., 2017). However, its reproduction is often impaired by inadequate extractive practices, since its parts, especially the leaves, flowers and bark, are often used in folk medicine, and its wood is also used for various purposes (Maia, 2012). Additionally, other biological and environmental factors, such as short annual production cycle of seeds, irregularity and uneven distribution of rainfall in the semiarid region from one year to the next, and seed dormancy (Alves et al., 2007), can interfere in obtaining catingueira seeds with the desired genetic and physiological qualities. To overcome these limitations, in vitro methods are an important alternative to complement the conservation and prevent the genetic erosion of the species.

In vitro conservation is based on tissue culture techniques and is a complementary strategy to conventional preservation methods. These biotechnological techniques have various advantages, such as production of plants free of pathogens and high multiplication rates under controlled aseptic conditions, reducing the requirements for quarantine and the labor and space necessary for conservation (Pacheco et al., 2016). Besides these advantages, it facilitates the availability of germplasm for use in genetic improvement programs (Arrigoni-Blank et al., 2014), and can be realized by changes in the culture conditions aiming to decelerate or totally suppress the growth of cells, tissues and organs, for the purpose of maximizing the interval between subcultures, or extending a single culture indefinitely.

The slow growth storage technique consists of slowing down or stopping the physiological metabolism of plants, to minimize the in vitro development and increase the in vitro period of the explant, without altering the genetic uniformity (or standard) of micropropagated plants (Kamińska et al., 2016). When reducing the in vitro metabolism of plants, the culture conditions such as temperature, light period and intensity and components of the culture medium (organic and inorganic nutrients, osmotic and growth regulators) can be altered during the incubation period (Singh; Kumar; Singh, 2015; Thakur; Tiwari; Jadhav, 2015; Kaur et al., 2012).

Various studies have been published on the in vitro conservation of plants by inducing slow growth, investigating species such as Ipomoea batatas L. (Arrigoni-Blank et al., 2014), Acanthostachys strobilacea
(Schult. f.) Link, Klotzsch and Otto (Carvalho; Santos; Nievol, 2014), Trichosanthes dioica Roxb. (Singh; Kumar; Singh, 2015), Cynara cardunculus var. scolymus L. (Tavazza et al., 2015), Globba marantina L. (Parida; Mohanty; Nayak, 2018), Heliconia champneiana cv. Splash (Rodrigues; Arruda; Forti, 2018), and Phoenix dactylifera L. (El-Dawayati; Baki; Abdelgalil, 2018). To the best of our knowledge, no in vitro germplasm preservation of $P$. pyramidalis has been reported.

The employment of osmotic agents such as sorbitol, mannitol, sucrose and ribose has been shown to be efficient in inducing slow growth of plants (George, 2008; Huang et al., 2014; Parida; Mohanty; Nayak, 2018). When added to the culture medium, these carbohydrates reduce the water potential and restrict the water availability to the explants (Shibli et al., 2006; Huang et al., 2014), significantly increasing the in vitro storage time of the tissues (Sharaf et al., 2012). Paclobutrazol (PBZ), a triazole, has been widely used to decrease the height of many plant species, by inhibiting the synthesis of gibberellins (Upreti et al., 2013; Kamran et al., 2018a; Kamran et al., 2018b).

Therefore, the objective of this work was to evaluate the effect of the osmotic agents sucrose, sorbitol and mannitol and the growth retardant paclobutrazol (PBZ) on the induction of slow growth in vitro of $P$. pyramidalis, seeking to establish alternative techniques for ex situ conservation of the species.

\section{MATERIAL AND METHODS}

\section{Location of the experiment, plant material and culture conditions}

The experiments were conducted in the Plant Tissue Culture Laboratory, part of the Experimental Forest Garden Unit of Feira de Santana State University, located in the city of the same name in the state of Bahia, Brazil. The $P$. pyramidalis seeds were collected in the rural zone

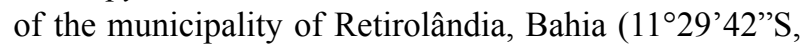
$39^{\circ} 25^{\prime} 32^{\prime \prime}$ W. $293 \mathrm{~m}$ ) and stored in a refrigerator at a temperature of $5^{\circ} \mathrm{C}$ in the Plant Tissue Culture Laboratory, where they remained until the start of the experiment. The explants used were $P$. pyramidalis plantlets with seven days of age, obtained from germinating seeds in test tubes containing woody plant medium (WPM) (Lloyd; McCown, 1980) (Figures 1a-d).

The seeds were washed with water and neutral detergent for five minutes and then rinsed with tap water for 30 minutes, followed by disinfestation by immersion for 10 minutes in a solution of the fungicide Derosal ${ }^{\circledR}(2$ $\mathrm{mL} \mathrm{L}^{-1}$ ), for 1 minute in $70 \%$ alcohol, and for 15 minutes 
in sodium hypochlorite ( $2.5 \%$ active chlorine) with two droplets of neutral detergent. Finally, they were washed in sterile distilled water three times and inoculated in test tubes $(25 \mathrm{~mm} \times 150 \mathrm{~mm})$ containing $15 \mathrm{~mL}$ of WPM solidified with agar $(0.7 \% \mathrm{w} / \mathrm{v})$ supplemented with specific concentrations of carbohydrates (as defined in experiments 1 and 2).

The $\mathrm{pH}$ of all media were adjusted to 5.6 with sodium hydroxide or hydrochloric acid, and $0.8 \% \mathrm{w} / \mathrm{v}$ agar was added before autoclaving at a temperature of $121^{\circ} \mathrm{C}$ and pressure of $1.05 \mathrm{~kg} / \mathrm{cm}^{2}$ for $15 \mathrm{~min}$. After sterilization, the explants were inoculated onto the medium and were incubated at $25 \pm 2{ }^{\circ} \mathrm{C}$ under $16 / 8 \mathrm{~h}$ photoperiod with light intensity of $50 \mu \mathrm{mol} \mathrm{m}^{-2} \mathrm{~s}^{-1}$.

\section{In vitro conservation of Poincianella pyramidalis by slow growth culture}

In the first experiment, the culture medium was supplemented with sucrose (Suc), sorbitol (Sorb) and/or mannitol (Man), to confer different osmotic potentials to the media $\left(\Psi_{0}=-0.2170,-0.3255,-0.4340,-0.651,-0.434\right.$ -0.5425 or $-0.868 \mathrm{MPa})$. The concentrations of Suc $(87.64$, $131.46,175.28$ or $219.10 \mathrm{mM})$ were combined with concentrations of Sorb $(0.0$ or $87.64 \mathrm{mM})$ or Man $(0.0$ or $87.64 \mathrm{mM}$ ), as listed in Table 1. The experimental design was completely randomized, with 10 repetitions and 8 tubes per repetition.

In the second experiment, the culture medium contained different concentrations $(0.0,1.5,3.0,4.5$ or 6.0 $\mu \mathrm{M})$ of PBZ and supplemented with $87.64 \mathrm{mM}$ of sucrose. The experimental design was completely randomized, with 10 repetitions and 10 tubes per repetition.

In both experiments the survival percentage was evaluated every 60 days, according to the interaction of the factors culture time $\mathrm{x}$ osmotic agent and culture time $\mathrm{x}$ PBZ concentration. At the end of 240 days, the following parameters were recorded: number of green leaves (NGL), length of aerial part (LAP), number of senescent leaves (NSL), length of the longest root (RL), dry mass of the aerial part (DMAP) and dry mass of the roots (DMR). The cultures were kept in a growth room under controlled conditions of temperature $\left(25 \pm 2^{\circ} \mathrm{C}\right)$, photoperiod $(16 / 8 \mathrm{~h})$ and photosynthetically active radiation $\left(60 \mu \mathrm{mol} \cdot \mathrm{m}^{-2} \mathrm{~s}^{-1}\right)$.

\section{Statistical analysis}

For statistical analysis, the survival percentage data were transformed into arcsine $\sqrt{x / 100}$ for normalization and homogenization of the variances and then submitted to analysis of variance (ANOVA), and the means were compared by the Scott-Knott test at 5\% probability. In complementation, regression analysis was also used for the quantitative factors related to culture time and concentrations of PBZ, and the mathematical models were chosen according to equations with the best fits, confirmed by the highest coefficients of determination $\left(\mathrm{R}^{2}\right)$ and the F-test for regression, both at $5 \%$ probability. All the statistical procedures were performed with the SAS 9.2 software (SAS Institute, 2009).
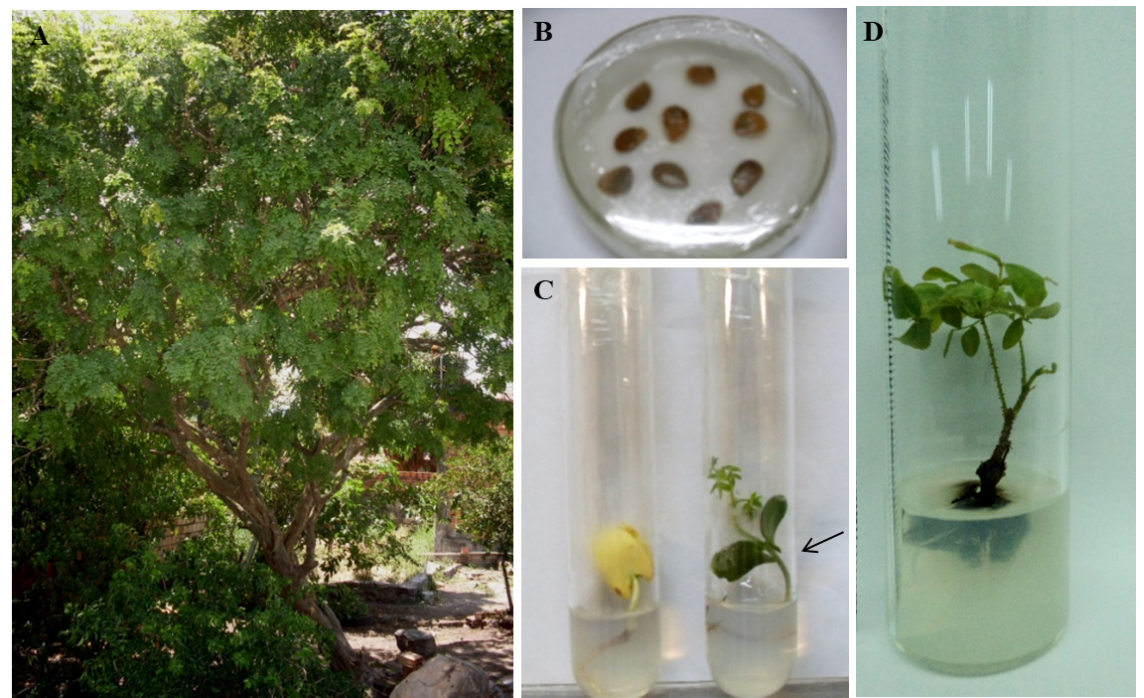

Figure 1: In vitro propagation of $P$. pyramidalis using explants. A) Plant of $P$. pyramidalis in its natural habitat. B) Establishment of the seeds in the culture medium. C) Germination of the seeds after 7 and 15 days (arrow) in the culture medium. D) Aspect of a P. pyramidalis plantlet after culture for 30 days. 


\section{RESULTS AND DISCUSSION}

\section{Effect of the osmotic agents}

The survival percentage of the P. pyramidalis plants declined significantly with increasing in vitro culture time ( $p \leq 0.05)$ during the subcultures in all the media tested. After 240 days, the highest survival rates of the catingueira plants were obtained on the medium only supplemented with sucrose: M3 with $77.78 \%$ (Table 2; Figure 2a), M4 with $72.78 \%$, M1 with $68.05 \%$ and M2 with $67.46 \%$ (Table 2).

The majority of the culture media supplemented with the osmotic agents sorbitol and mannitol produced low survival rates, except M5, containing sorbitol, in which $66.07 \%$ of the plants survived. On the other hand, when the sorbitol concentration was doubled (M7), the survival percentage was the lowest, at $14.39 \%$, although belonging to the same treatment group as M8 (17.26\%).

Studies performed with other species have produced divergent results regarding survival rates of plants conserved in vitro and submitted to slow growth induced by osmotic agents. El-Bahr et al. (2016), investigating three osmotic substances (sucrose, mannitol and sorbitol) for in vitro conservation to two date palm cultivars (Phoenix dactylifera L.) under slow growth observed that the culture medium containing only sucrose promoted the highest survival of the plants of the Sakkoty cultivar, while for the Bartamoda cultivar the highest survival percentages were obtained with the medium supplemented with $219.57 \mathrm{mM}$ or $329.35 \mathrm{mM}$ of mannitol and $109.78 \mathrm{~m} \mathrm{mM}$ of sorbitol.

Parida, Mohanty and Nayak, (2018) also observed a variable survival rate of Globba marantina L. plants conserved in vitro in response to the osmotic agents used, finding that in MS medium supplemented with kinetin $(13.93 \mu \mathrm{M})$, naphthalene acetic acid $(2.68 \mu \mathrm{M})$ and sucrose $(87 \mu \mathrm{M})$, the conservation with survival rate of $60.0 \%$ was 200 days. However, when using MS medium plus $29 \mathrm{mM}$ of sucrose and $54 \mathrm{mM}$ of mannitol, the conservation period with survival rate of $60.0 \%$ was 220 days.

Tuhin and Biswajit (2012) observed that the addition of sorbitol and mannitol, both at concentration de $58 \mathrm{mM}$ in the medium increased the survival percentage $(85.0 \%)$ of Withania somnifera L. plants conserved in vitro for 8 months compared to the control treatment with $87 \mathrm{mM}$ of sucrose. However, the authors observed a decline in the survival rate and growth of the plants when sorbitol and mannitol were both added to the medium at concentration of $87 \mathrm{mM}$. Analogously, other authors have reported a phytotoxic effect of these osmotic agents on various plant species, such as $A$. racemosus Willd (Thakur; Tiwari; Jadhav, 2015) and Piper aduncum L. and Piper hispidinervum C. DC. (Silva; Scherwinski-Pereira, 2011).

Although sorbitol and mannitol are used to promote in vitro conservation, these carbohydrates, depending on the concentration or species in question, can have a phytotoxic effect, as observed in this study with $P$. pyramidalis.

Table 1: Culture media used for in vitro conservation of $P$. piramidalis using different osmotic agents.

\begin{tabular}{ccccc}
\hline \multirow{2}{*}{ Media } & \multicolumn{3}{c}{ Concentration of osmotic agents $(\mathrm{mM})$} & $* \Psi_{\mathrm{O}}(\mathrm{MPa})$ \\
\cline { 2 - 5 } & Sucrose & Sorbitol & Mannitol & \\
\hline M1 & 87.64 & 0 & 0 & -0.2170 \\
M2 & 131.46 & 0 & 0 & -0.3255 \\
M3 & 175.28 & 0 & 0 & -0.4340 \\
M4 & 219.10 & 0 & 0 & -0.6510 \\
M5 & 87.64 & 87.64 & 0 & -0.4340 \\
M6 & 131.46 & 87.64 & 0 & -0.5425 \\
M7 & 175.28 & 87.64 & 0 & -0.6510 \\
M8 & 219.10 & 87.64 & 0 & -0.8680 \\
M9 & 87.64 & 0 & 87.64 & -0.4340 \\
M10 & 131.46 & 0 & 87.64 & -0.5425 \\
M11 & 175.28 & 0 & 87.64 & -0.6510 \\
M12 & 219.10 & 0 & 87.64 & -0.8680 \\
\hline
\end{tabular}

*Osmotic potential. 
Table 2: Survival percentage of $P$. pyramidalis plants grown on culture medium containing different concentrations of the osmotic agents sucrose, sorbitol and mannitol.

\begin{tabular}{ccccc}
\hline \multirow{2}{*}{ Media } & \multicolumn{4}{c}{ Survival percentage / Subculture (days) } \\
\cline { 2 - 5 } M1 & $100.00 \mathrm{Aa}$ & $93.45 \mathrm{bB}$ & $88.39 \mathrm{bB}$ & $68.05 \mathrm{aC}$ \\
M2 & $100.00 \mathrm{aA}$ & $96.81 \mathrm{aA}$ & $88.94 \mathrm{bB}$ & $67.46 \mathrm{aC}$ \\
M3 & $100.00 \mathrm{aA}$ & $96.81 \mathrm{aA}$ & $83.79 \mathrm{bB}$ & $77.77 \mathrm{aB}$ \\
M4 & $100.00 \mathrm{aA}$ & $94.63 \mathrm{bB}$ & $83.52 \mathrm{bC}$ & $72.78 \mathrm{aC}$ \\
M5 & $100.00 \mathrm{aA}$ & $97.92 \mathrm{aA}$ & $93.16 \mathrm{aA}$ & $66.07 \mathrm{aB}$ \\
M6 & $100.00 \mathrm{aA}$ & $97.61 \mathrm{aA}$ & $54.76 \mathrm{~dB}$ & $24.60 \mathrm{bC}$ \\
M7 & $100.00 \mathrm{aA}$ & $86.36 \mathrm{cB}$ & $48.33 \mathrm{eC}$ & $14.39 \mathrm{cD}$ \\
M8 & $100.00 \mathrm{aA}$ & $89.82 \mathrm{bB}$ & $43.52 \mathrm{eC}$ & $17.26 \mathrm{cD}$ \\
M9 & $100.00 \mathrm{aA}$ & $82.44 \mathrm{cB}$ & $52.38 \mathrm{eC}$ & $26.67 \mathrm{bD}$ \\
M10 & $100.00 \mathrm{aA}$ & $80.09 \mathrm{cB}$ & $69.22 \mathrm{cB}$ & $33.88 \mathrm{bC}$ \\
M11 & $100.00 \mathrm{aA}$ & $70.42 \mathrm{~dB}$ & $40.00 \mathrm{dC}$ & $25.55 \mathrm{bC}$ \\
M12 & $100.00 \mathrm{aA}$ & $81.25 \mathrm{cB}$ & $57.14 \mathrm{dC}$ & $30.00 \mathrm{bD}$ \\
CV (\%) & 9.23 & & & \\
\hline
\end{tabular}

M1: 87.64 mM Sac; M2: 131.46 mM Sac; M3: 175.28 mM Sac; M4: 219.10 mM Sac; M5: 87.64 mM Sac + 87.64 mM Sorb; M6: 131.46 mM Sac + 87.64 mM Sorb; M7: 175.28 mM Sac + 87.64 mM Sorb; M8: 219.10 mM Sac + 87.64 mM Sorb; M9: 87.64 mM Sac + 87.64 mM Man; M10: 131.46 mM Sac + 87.64 mM Man; M11: 175.28 mM Sac + 87.64 mM Man; M12: 219.10 mM Sac + 87.64 $\mathrm{mM}$ Man. Means followed by the same lower-case letters (conservation period) and same upper-case letters (medium) do not differ according to the Scott-Knott test and Tukey test, respectively, $(p \leq 0.01)$.
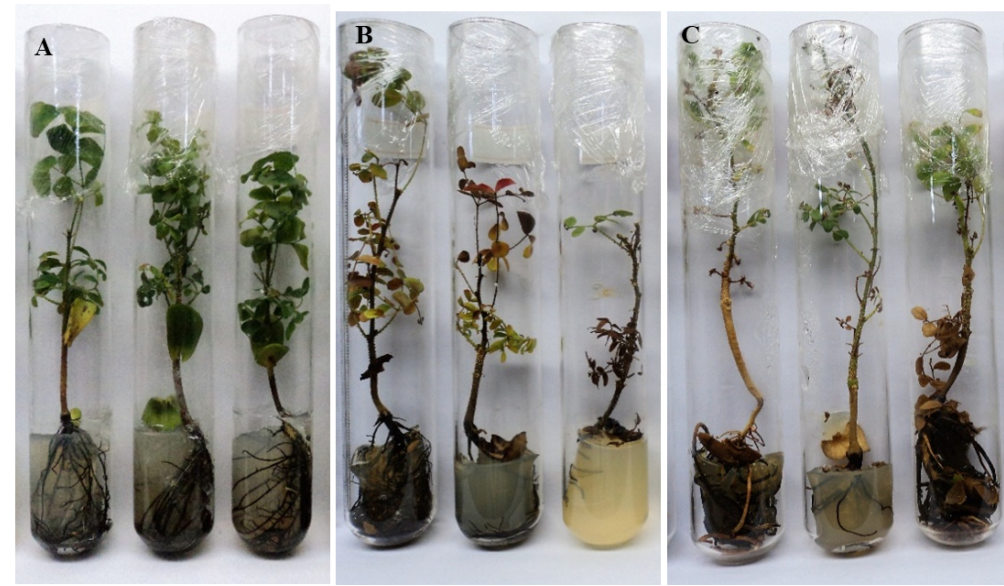

Figure 2: A) In vitro conservation by slow growth storage after 240 days in medium supplemented with 175.28 of sucrose (M3). B) Presence of senescent leaves, lack of vigor, poor development and irregular growth of the aerial part when the plants were cultured in medium containing $219.10 \mathrm{mM}$ of sucrose and $87.64 \mathrm{mM}$ of mannitol (M12). C) Aspect of the $P$. pyramidalis plants in culture medium supplemented with $6.0 \mu \mathrm{M}$ PBZ. 
The addition of sorbitol and mannitol to the culture medium caused a significant reduction in the number of green leaves per plant (Figure 3a). This reduction was directly proportional to the increase in the concentrations of the carbohydrates combined, as recorded in treatments M7 (0.58), M8 (1.25) M11 and M12 (1.67) and M5 (1.88), except in treatments M6, M9 and M10, in which the average numbers of leaves/plant were $2.42,2.17$ and 3.10 , respectively, although these belong to the same group of treatments as M1, M2, M3 and M4, in which the culture media only contained sucrose as the osmotic agent (Figure 2a). Bello-Bello et al. (2014) also observed a smaller number of leaves of Succharum sp. when cultured in a medium containing high concentrations of carbohydrates
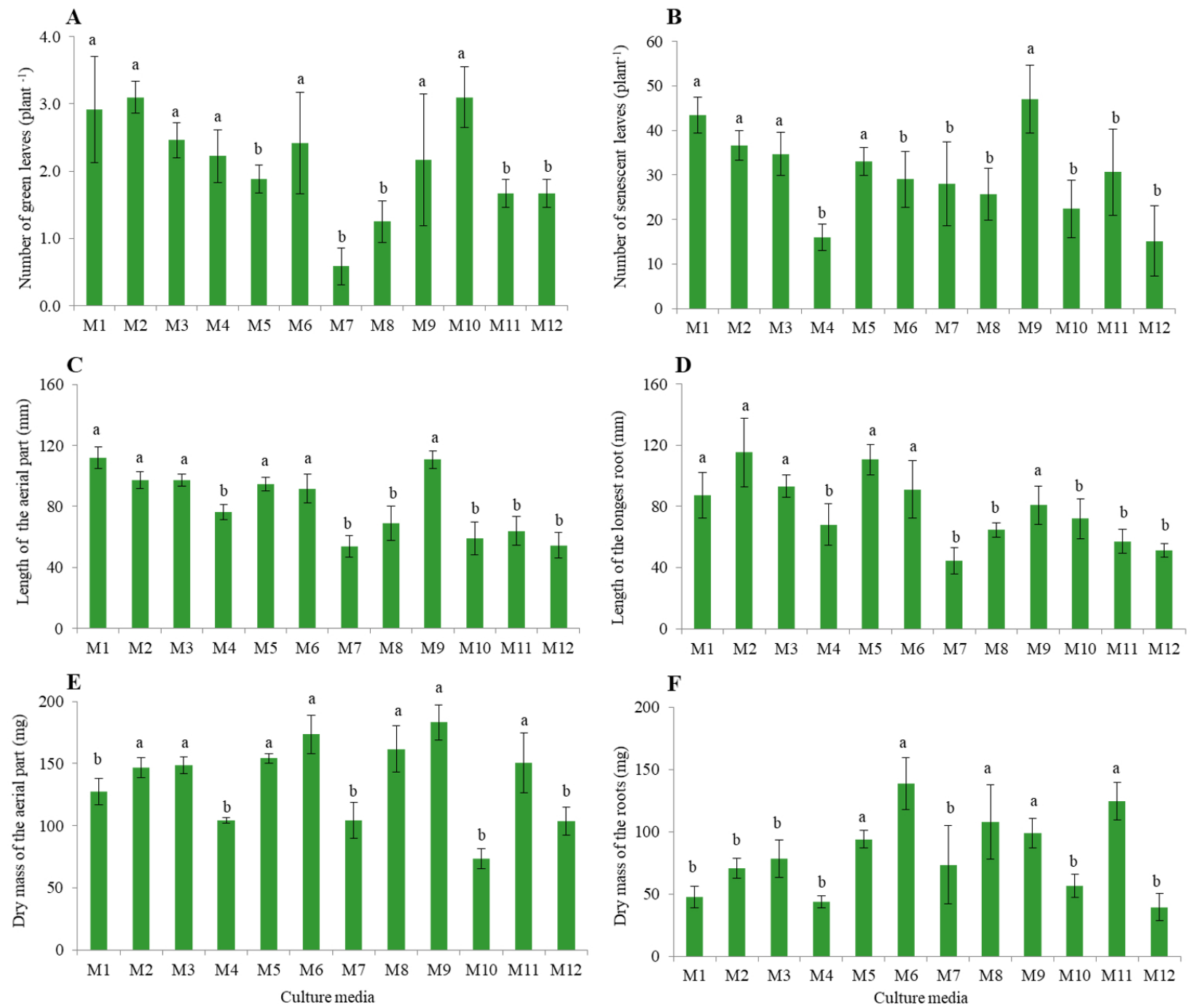

Figure 3: Number of green leaves (a), number of senescent leaves (b), length of the aerial part (c), length of the longest root (d), dry mass of the aerial part (e) and dry mass of the roots (f) of $P$. pyramidalis plants after growth of 240 days in culture media containing different concentrations of osmotic agents. M1: 87.64 mM Sac; M2: 131.46 mM Sac; M3: 175.28 mM Sac; M4: 219.10 mM Sac; M5: 87.64 mM Sac + 87.64 mM Sorb; M6: 131.46 mM Sac + 87.64 mM Sorb; M7: 175.28 mM Sac + 87.64 mM Sorb; M8: 219.10 mM Sac + 87.64 mM Sorb; M9: 87.64 mM Sac + 87.64 mM Man; M10: 131.46 mM Sac + 87.64 mM Man; M11: 175.28 mM Sac + 87.64 mM Man; M12: 219.10 mM $\mathrm{Sac}+87.64 \mathrm{mM}$ Man. Means followed by the same letter belong to the same group by the Scott-Knott test at $5 \%$ probability. 
For the number of senescent leaves, there was a significant effect of the osmotic agents used in the conservation medium of $P$. pyramidalis (Figure $3 \mathrm{~b}$ ). The plants from the M9 treatment presented the largest number of senescent leaves, with 47.00, although belonging to the same group as treatments M1, M2, M3 and M5, with 43.47, 36.67, 34.74 and 33.03 senescent leaves/plant, respectively. On the other hand, the lowest numbers of senescent leaves were observed in the plants grown in the media of treatments M4 (15.94), M6 (29.00), M7 (28.08), M8 (25.67), M10 (22.36), M11 (30.67) and M12 (15.17), the majority of them containing only sorbitol or mannitol as osmotic agent, the exception being M4, containing only sucrose (Figure 3b). Although the plants grown in the culture media supplemented with sorbitol or mannitol produced a low number of senescent leaves, these plants' development was limited, including atrophy in many cases, so these media are not recommended for in vitro conservation (data not shown).

The presence of senescence is not desirable for in vitro growth, mainly when the objective is conservation of germplasm, because it requires a new subculture for the plants to regain their vigor and capacity for regeneration (Canto et al., 2004). Unlike what was observed for $P$. pyramidalis, Sá; Ledo; Ledo (2011) reported a reduction of foliar abscission when using high concentrations of mannitol in cultures of Hancornia speciosa Gomes, although observing a deleterious effect on the explants.

Recent studies have demonstrated that the in vitro culture conditions for short and medium-term conservation cause an increase in the oxidative stress and senescence (Thakur; Tiwari; Jadhav, 2015; El-Dawayati; Baki; Abdelgalil, 2018), with increased accumulation of ethylene in the culture micro-environment being one of the possible causes of this senescence. In this process, some organelles are destroyed and the chloroplasts are the first to deteriorate with the leaf senescence (Taiz; Zeiger, 2009), physiologically explaining the symptoms of lightening of the senescent leaves.

The length of the aerial part declined significantly with increasing concentrations of the osmotic agents added to the culture medium. The lowest values were observed in M7 (53.75 mm), M12 (54.50 mm), M10 (58.95 mm), M11 $(60.00 \mathrm{~mm})$, M8 $(69.17 \mathrm{~mm})$ and M4 (76.28 mm) (Figure 3c). The addition of mannitol or sorbitol alone was efficient to reduce the growth of the P. pyramidalis plants. However, when these osmotic agents were combined with high concentrations of sucrose, the plants after culture for 240 days presented lack of vigor, poor development and irregular growth of the aerial part (Figure $2 b$ )
Analogously to the observation in this study, other researchers have observed that the addition of the osmotic agents mannitol or sorbitol together with sucrose was efficient in reducing the growth of other plant species, such as Passiflora gibertii N.E. Brown (Faria et al., 2006), Glycyrrhiza glabra L. (Srivastava et al., 2013) and $A$. racemosus (Thakur; Tiwari; Jadhav, 2015).

With respect to the length of the main root, the $P$. pyramidalis plants from treatments M4, M7, M8, M10, M11 and M12 presented the smallest averages, with 68.11 $\mathrm{mm}, 44.50 \mathrm{~mm}, 64.75 \mathrm{~mm}, 71.97 \mathrm{~mm}, 57.00 \mathrm{~mm}$ and 51.00 $\mathrm{mm}$, respectively (Figure 3d). The decreased length of the main root of $P$. pyramidalis in function of reduction of the osmotic potential of the culture medium corroborates the results of Marino et al., (2010) and Bello-Bello et al. (2014) in plants of cv San Castrese and Boreale and Succharum sp., respectively.

For dry mass of the aerial part, the smallest values $(127.61 \mathrm{mg}, 104.29 \mathrm{mg}, 104.19 \mathrm{mg}, 73.34 \mathrm{mg}$ and $103.60 \mathrm{mg}$ ) were obtained in treatments M1, M4, M7, M10 and M12, respectively (Figure 3e). In turn, for the dry mass of the roots, the smallest averages were obtained in treatments M1, M2, M3, M4, M7, M10 and M12, with respective values of $47.64 \mathrm{mg}$, $70.63 \mathrm{mg}, 78.38 \mathrm{mg}, 43.79 \mathrm{mg}, 73.34 \mathrm{mg}, 56.50 \mathrm{mg}$ and $39.23 \mathrm{mg}$ (Figure 3f). The decrease in the dry mass of the aerial part and roots of $P$. pyramidalis with reduction of osmotic potential of the culture medium can possibly be explained by the action of the osmotic agents when added to the medium, by reducing the water potential and availability of water and nutrients in the medium, inducing slower growth (Huang et al., 2014; El-Bahr et al., 2016). Therefore, the reduction in the growth of the P. pyramidalis plants, reflected in the lower dry mass values, is an advantage for in vitro conservation, where the aim is to minimize the growth of the plants to increase the interval between subcultures. However, in this study the increase in the concentration of the combined carbohydrates in the culture medium, although favoring slower growth of the $P$. pyramidalis plants, is not recommended for in vitro conservation of this species, sience the plants' vigor diminished.

\section{Effect of paclobutrazol (PBZ)}

The application of the growth retardant PBZ significantly influenced $(p \leq 0.05)$ the variables survival percentage, number of green leaves, dry masses of the aerial part and root (Figure 4; Figure 5). However, the opposite effect was observed for length of the aerial part, number of senescent leaves and length of the longest 
root, since the use of PBZ in the culture medium did not significantly influence $(p \geq 0.05)$ these characters.

In the present study, the survival percentage of the catingueira plants, with a decrease during the culture period with all concentrations tested. At the end of 240 days, the highest survival rate $(75.63 \%)$ was obtained when the culture medium was supplemented with $6.0 \mu \mathrm{M}$ of PBZ (Figure 4; Figure 2c). However, the plants obtained in the control treatment (absence of PBZ) presented a survival rate of $68.06 \%$, higher than observed with PBZ concentrations of $1.5 \mu \mathrm{M}, 3.0 \mu \mathrm{M}$ and $4.5 \mu \mathrm{M}$ (Figure 4). In contrast, other studies have reported $100 \%$ survival after culture for 180 days in a medium supplemented with 10.2 $\mu \mathrm{M}$ for in vitro conservation of Succharum sp. (Bello-Bello et al., 2014) and Vanilla planifolia Jacks (Bello-Bello; Garcia-Garcia; Iglesias-Andreu (2015).

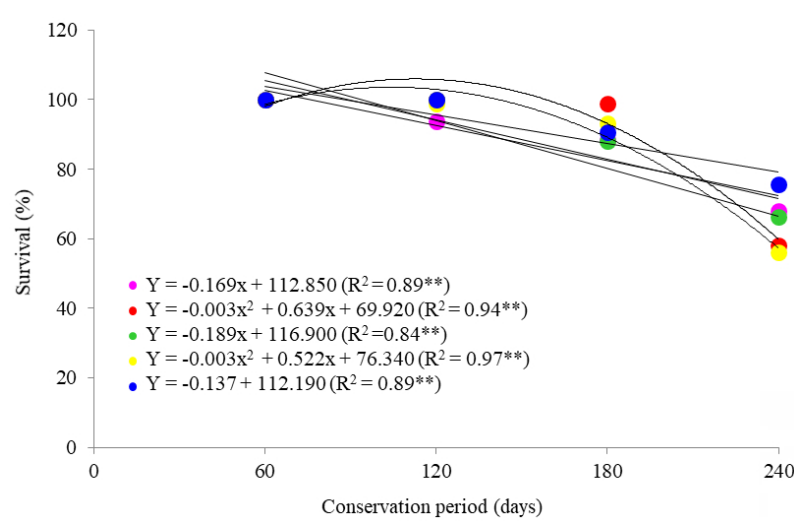

Figure 4: Survival percentage of $P$. pyramidalis plants during growth in conservation medium containing different concentrations of the growth retardant PBZ: - $0.0 \mu \mathrm{M}$ (pink circle); $1.5 \mu \mathrm{M}$ (red circle); $3.0 \mu \mathrm{M}$ (green circle); $\bullet 4.5 \mu \mathrm{M}$ (yellow circle) and $\bullet 6.0 \mu \mathrm{M}$ (blue circle). **Highly significant $(p \leq 0.01)$ and * Significant $(p \leq 0.05)$ by the F-test.

PBZ is an active compound that affects the subapical meristems of plants, inhibiting the oxidation of kaurene to kaurenoic acid, which is a precursor of gibberellic acid, resulting in reduced cell division without causing cytotoxicity (Tanimoto, 2005; Negi; Lal; Sah, 2017). These characteristics can directly influence plants' survival over time, since the diminished cell division can reduce the plant metabolism. However, the ideal concentrations of PBZ vary greatly with the species.

The number of leaves was described by a quadratic equation with increasing concentration of the growth regulator PBZ in the culture medium. The largest number of leaves per plant (4.4) was obtained at the concentration of $4.5 \mu \mathrm{M}$, while the lowest number of leaves/plant (2.61) was observed in the control treatment, $68.58 \%$ lower than the best result (Figure 5a). In pineapple (Ananas comosus L.), a greater number of green leaves was observed in the absence PBZ (Canto et al., 2004), while in citrus ( Citrus volkameriana Pasq.), no alteration was observed in the average number of leaves with the use of PBZ (Siqueira; Cecon; Salomão, 2008).

With respect to the dry mass of the aerial part, the highest average (131.35 mg) was obtained without PBZ (Figure 5b). The reduction in this variable observed in response to the treatments containing PBZ can be explained by the hormonal inhibition action, because paclobutrazol is a triazole that blocks the biosynthesis of $\mathrm{GA}_{3}$ (gibberellic acid), which is among the hormones that has the greatest influence on the growth and height of plants (Kamran et al., 2018b). Nepomuceno et al. (2007) also reported a reduction of the dry mass of the aerial part of Anadenanthera colubrina (Vell.) Brenan plants treated with the highest concentration of PBZ $(13.6 \mu \mathrm{M})$, of $32.9 \%$ compared with the control treatment. The addition of PBZ also presented a quadratic effect on the root dry mass. There was a significant increase in this dry mass of the plants treated with PBZ in relation to the control treatment (51.06 mg). The plants cultured with PBZ concentration of $6 \mu \mathrm{M}$ produced the highest root dry mass, of 158.77 $\mathrm{mg}$ (Figure 5c).

It is interesting to note that the roots of $P$. pyramidalis from the treatments containing PBZ, independent of the concentration tested, were visibly thicker (Figure 2c), which likely influenced the root dry mass. Some authors have stated that the root thickening effect is a reflection of the secondary effect caused by physiological alterations of the drain force in the plant, with higher partition of photoassimilates (Tekalign; Hammes, 2005). This possibly contributed to the larger root system of the catingueira plants submitted to the treatment with this triazole. Similar behavior was reported by Thakur et al. (2006) in Lilium longiflorum Wall. and by Nepomuceno et al. (2007) in Anadenanthera colubrina (Vell.) Brenan var. cebil (Griseb) Altschul., who also observed thicker roots in the plants treated with PBZ.

The action of PBZ has been associated with decreases in transpiration and plant height, increases in biomass and leaf area, root thickening and enhanced stress resistance (Te-Chato; Nujeen; Muangsorn, 2009; Negi; Lal; Sah, 2017). These traits can indicate the plant has better adaptive mechanisms for ex vitro conservation. 

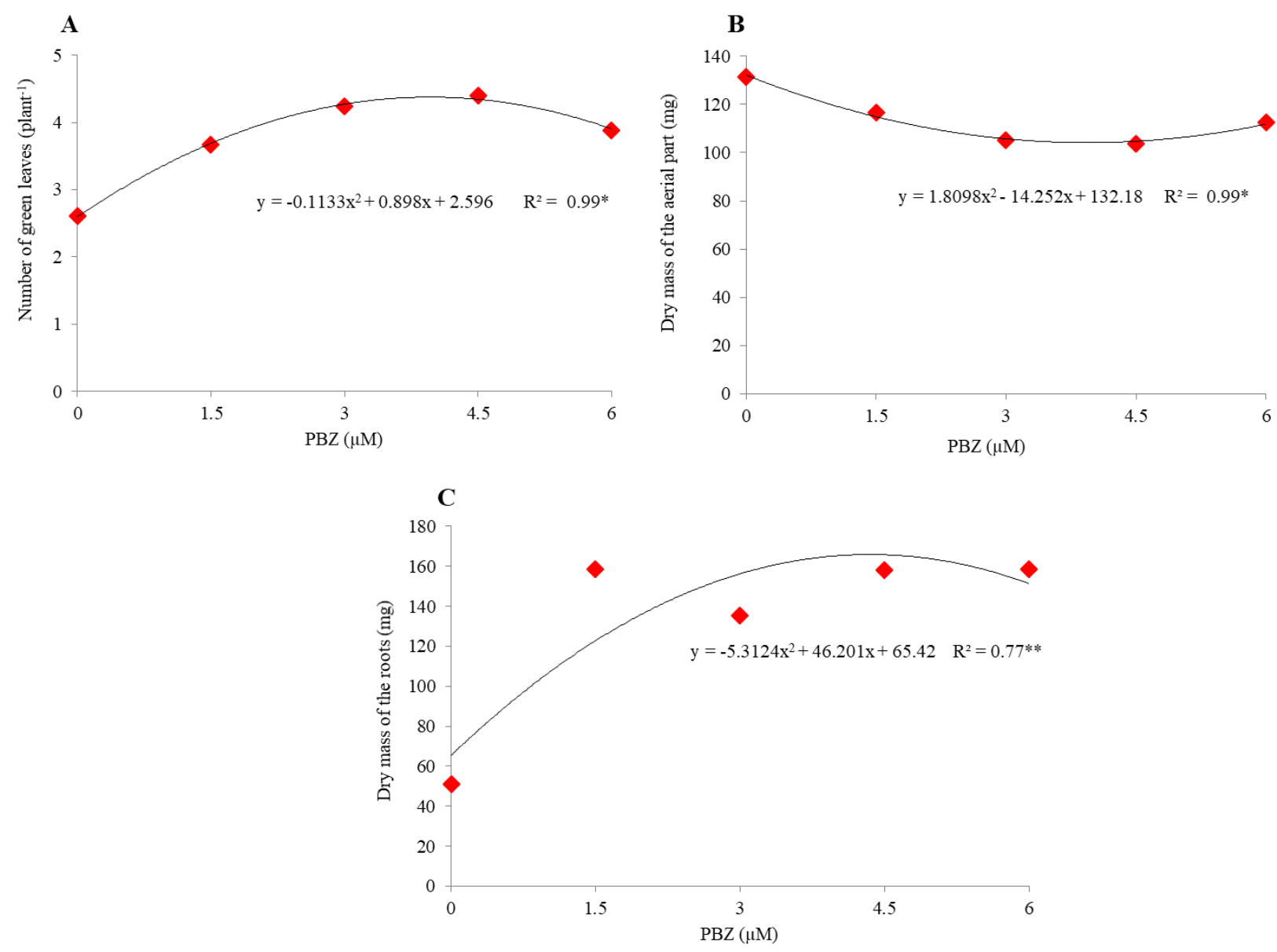

Figure 5: A) Number of green leaves; B) Dry mass of the aerial part; C) Dry mass of the roots of $P$. pyramidalis plants evaluated after conservation for 240 days in culture media containing different concentrations of paclobutrazol (PBZ). ** Highly significant $(p \leq 0.01)$ and * Significant $(p \leq 0.05)$ by the F-test

\section{CONCLUSIONS}

The results obtained in this study demonstrate that sorbitol and mannitol resulted in lower survival rates and therefore are not effective for in vitro conservation of $P$. pyramidalis. The best results to maintain the quality of the $P$. pyramidalis plants conserved in vitro were obtained on medium supplemented with 219.10 $\mathrm{mM}$ of sucrose by itself for up to 240 days without subculture. With respect to PBZ, the concentration of $6.0 \mu \mathrm{M}$ can be recommended for in vitro conservation of $P$. pyramidalis for 240 days without the need for subculturing.

\section{ACKNOWLEDGMENTS}

We thank Feira de Santana State University for providing the physical support for the study, and the Office to Improve University Personnel (CAPES) for financial support (001) and for the postdoctoral research grant (PNPD 15950830814) to the third author (T.L.S.).

\section{REFERENCES}

ALVES, E. U. et al. Superação da dormência em semente de Caesalpinia pyramidalis Tul. Revista Árvore, 31(3):405415, 2007. 
ARRIGONI-BLANK, M. F. et al. In vitro conservation of sweet potato genotypes. The Science World Journal, 2014(1):1-7, 2014.

BELLO-BELLO, J. J.; GARCIA-GARCIA, G. G.; IGLESIAS-ANDREU, L. Conservación de vainilla (Vanilla planifolia Jacks.) bajo condiciones de lento crecimiento in vitro. Revista Fitotecnia Mexicana, 38(2):165-171, 2015.

BELLO-BELLO, J. J. et al. Comparación del efecto de osmorreguladores e inhibidores del crecimiento en la conservación in vitro de caña de azúcar. Agrociencia, 48(4):439-446, 2014.

CANTO, A. M. M. E. et al. Conservação in vitro de germoplasma de abacaxi tratado com paclobutrazol. Pesquisa Agropecuária Brasileira, 39(7):717-720, 2004.

CARVALHO, P. E. R. Espécies arbóreas brasileiras. Brasília: Embrapa Informação Tecnológica, 2014. 22p.

CARVALHO, V.; SANTOS, D. S.; NIEVOL, C. C. In vitro storage under slow growth and ex vitro acclimatization of the ornamental bromeliad Acanthostachys strobilacea. South African Journal of Botany, 92(1):39-43, 2014.

CHAVES, T. P. et al. Evaluation of the interaction between the Poincianella pyramidalis (Tul.) LP Queiroz extract and antimicrobials using biological and analytical models. Plos One, 18(5):1-23, 2016.

DIAS JÚNIOR, A. F. et al. Pyrolysis and wood by-products of species from the brazilian semi-arid region. Scientia Forestalis, 46(117):65-75, 2018.

EL-BAHR, M. K. et al. In vitro conservation of embryogenic cultures of date palm using osmotic mediated growth agents. Journal of Genetic Engineering and Biotechnology, 14(2):363-370, 2016.

EL-DAWAYATI, M. M.; BAKI, M. A. A.; ABDELGALIL, L. M. Effect of different conservation period with different sucrose concentrations on conserving somatic embryo clusters of date palm (Phoenix dactylifera L.) under minimal growth conditions. Applied Science Reports, 21(1):14-21, 2018.

FARIA, G. A. et al. Sucrose and sorbitol effect in the in vitro conservation of Passiflora gibertii N E. Brown. Revista Brasileira de Fruticultura, 28(2):267-270, 2006.

GEORGE, E. F. Plant Tissue Culture Procedure-Background. In: GEORGE, E. F.; HALL, M. A.; KLERK, G. J. Plant propagation by tissue culture. Dordrecht: Springer, 2008. v.1, p.1-28.

GOMES-COPELAND, K. K. P. et al. In vitro callogenesis of Poincianella pyramidalis (catingueira). Revista Brasileira de Farmacognosia, 27(4):525-528, 2017.
HUANG, H. P. et al. Germplasm preservation in vitro of Polygonum multiflorum Thunb. Pharmacognosy Magazine, 10(38):179-184, 2014

KAMIŃSKA, M. et al. Effect of light conditions and ABA on cold storage and post-storage propagation of Taraxacum pieninicum. Plant Cell, Tissue and Organ Culture, 127(1):25-34, 2016

KAMRAN, M. et al. Application of paclobutrazol affect maize grain yield by regulating root morphological and physiological characteristics under a semi-arid region. Scientific Reports, 8(4018):1-15, 2018a.

KAMRAN, M. et al. Effect of paclobutrazol, a potential growth regulator on stalk mechanical strength, lignin accumulation and its relation with lodging resistance of maize. Plant Growth Regulation, 84(2):317-332, 2018b.

KAUR, D. et al. Changes in sugar levels during slow growth of Dendrocalamus hamiltonii somatic embryos due to liquid paraffin overlay. In vitro Cellular \& Developmental Biology - Plant, 48(1):120-126, 2012.

LEITE, A. V.; MACHADO, I. C. Biologia reprodutiva da "catingueira" (Caesalpinia pyramidalis Tul, LeguminosaeCaesalpinioideae), uma espécie endêmica da Caatinga. Revista Brasileira de Botânica, 32(1):79-88, 2009.

LLOYD, G.; MCCOWN, B. Use of microculture for production and improvement of Rhododendronn ssp. HortScience, 15:416-420, 1980.

MAIA, G. N. Caatinga, árvores e arbustos e suas utilidades. São Paulo: D \& Z. Computação gráfica e editora, 2004. $413 p$.

MAIA, G. N. Caatinga: árvores e arbustos e suas utilidades. Fortaleza: Printcolor Gráfica e Editora, 2012. 413p.

MARINO, G. et al. Effect of carbohydrates on in vitro lowtemperature storage of shoot cultures of apricot. Scientia Horticulturae, 126(4):434-440, 2010.

NEGI, S. S.; LAL, S.; SAH, H. Influence of growth retardant on vegetative growth and leaf chlorophyll content of jackfruit (Artocarpus heterophyllus). International Journal of Pure and Applied Bioscience, 5(1):142-146, 2017.

NEPOMUCENO, C. F. et al. Controle da abscisão foliar e morfogênese in vitro em culturas de Anadenanthera colubrina (Vell.) Brenan var. cebil (Griseb) Altschul. Revista Árvore, 31(5):967-975, 2007.

PACHECO, G. et al. In vitro conservation of Passiflora - A review. Scientia Horticulturae, 211(1):305-311, 2016. 
PARIDA, R.; MOHANTY, S.; NAYAK, S. In vitro plant regeneration potential of genetically stable Globba marantina L., Zingiberaceous species and its conservation. Proceedings of the National Academy of Sciences, India Section B: Biological Sciences, 88(1):321-327, 2018.

RODRIGUES, P. H.V.; ARRUDA, F.; FORTI, V. A. Slow-grown in vitro conservation of Heliconia champneiana cv. Splash. Scientia Agricola, 75(2):163-166, 2018.

SÁ, A. J.; LEDO, A. S.; LEDO, C. A. S. Conservação in vitro de mangabeira da região nordeste do Brasil. Ciência Rural, 41(1):57-62, 2011.

SAS INSTITUTE. SAS/STAT: user's Guide. Version 9.2. SAS Institute, 2009.

SHARAF, S. A. et al. Slow-growth preservation of wild shih (Artemisia herba-alba Asso.) microshoots from Jordan. Journal of Food, Agriculture and Environment 10(2):1359-1364, 2012.

SHIBLI, R. A. et al. In vitro conservation and cryopreservation of plant genetic resources: A review. World Journal of Agricultural Sciences, 2(4):372-382, 2006.

SILVA, T. L.; SCHERWINSKI-PEREIRA, J. E. In vitro conservation of Piper aduncum and Piper hispidinervum under slowgrowth conditions. Pesquisa Agropecuária Brasileira, 46(4):384-389, 2011.

SIQUEIRA, D. L.; CECON, P. R.; SALOMÃO, L. C. C. Desenvolvimento do limoeiro 'Volkameriano' (Citrus volkameriana Pasq.) submetido a doses de paclobutrazol e ácido geberélico. Revista Brasileira de Fruticultura, 30(3):764-768, 2008.

SINGH, H.; KUMAR, S.; SINGH, B. D. In vitro conservation of pointed gourd (Trichosanthes dioica) germplasm through slow-growth shoot cultures: Effect of flurprimidol and triiodobenzoic acid. Scientia Horticulturae, 182(1):4146, 2015.

SOUZA, C. S. et al. Agathisflavone, a flavonoid derived from Poincianella pyramidalis (Tul.), enhances neuronal population and protects against glutamate excitotoxicity. NeuroToxicology, 65(1):85-97, 2018.

SRIVASTAVA, M. et al. In vitro conservation of Glycyrrhiza glabra by slow growth culture. International Journal of Biological \& Medical Research, 3(1):49-58, 2013.

TAIZ, L.; ZEIGER, E. Fisiologia Vegetal. 4.ed. Porto Alegre: Artmed, 2009. 819p.

TANIMOTO, E. Regulation of root growth by plant hormones: Roles for auxin and gibberellin. Critical Reviews in Plant Sciences, 24(4):249-265, 2005.

TAVAZZA, R. et al. A validated slow-growth in vitro conservation protocol for globe artichoke germplasm: A cost-effective tool to preserve from wild to elite genotypes. Scientia Horticulturae, 197(1):135-143, 2015.

TE-CHATO, S.; NUJEEN, P.; MUANGSORN, S. Paclobutrazol enhance budbreak and flowering of Friederick's Dendrobium orchid in vitro. Journal of Agricultural Science and Technology, 5(1):157-165, 2009.

TEKALIGN, T.; HAMMES, P. S. Growth and biomass production in potato grown in the hot tropics as influenced by paclobutrazol. Plant Growth Regulation, 45(1):37-46, 2005.

THAKUR, R. et al. Regulation of growth of Lilium plantlets in liquid medium by application of paclobutrazol or ancymidol, for its amenability in a bioreactor system: Growth parameters. Plant Cell Reports, 25(5):382-391, 2006.

THAKUR, S.; TIWARI, K. L.; JADHAV, S. K. In vitro approaches for conservation of Asparagus racemosus Willd. In vitro Cellular \& Developmental Biology - Plant, 51(6):619-625, 2015.

TUHIN, C.; BISWAJIT, G. Mass propagation and in vitro conservation of indian ginseng - Withania somnifera (L.) Dunal. Global Journal of Research on Medicinal plants \& Indigenous Medicine, 1(10):529-538, 2012.

UPRETI, K. K. et al. Hormonal changes in response to paclobutrazol induced early flowering in mango cv. Totapuri. Scientia Horticulturae, 150(1):414-418, 2013. 